\title{
"The role of crowdfunding in entrepreneurial ventures: an analysis of recent trends in Sweden"
}

$\begin{array}{ll} & \text { Lars Silver } \\ \text { AUTHORS } & \text { Björn Berggren } \\ & \text { Andreas Fili }\end{array}$

Lars Silver, Björn Berggren and Andreas Fili (2016). The role of crowdfunding in

ARTICLE INFO entrepreneurial ventures: an analysis of recent trends in Sweden. Investment Management and Financial Innovations, 13(1-1), 221-229.

doi:10.21511/imfi.13(1-1).2016.09

DOI

http://dx.doi.org/10.21511/imfi.13(1-1).2016.09

RELEASED ON

Friday, 08 April 2016

JOURNAL

"Investment Management and Financial Innovations"

FOUNDER

LLC "Consulting Publishing Company "Business Perspectives"

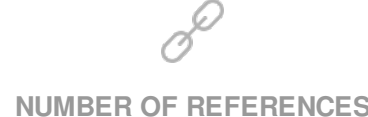

0

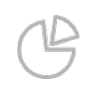

NUMBER OF FIGURES

0

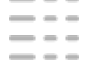

NUMBER OF TABLES

0

(C) The author(s) 2022. This publication is an open access article. 
Lars Silver (Sweden), Björn Berggren (Sweden), Andreas Fili (Sweden)

\title{
The role of crowdfunding in entrepreneurial ventures: an analysis of recent trends in Sweden
}

\begin{abstract}
The financing of entrepreneurial ventures has been at the forefront of academic debate as well as policy-making discussion for almost a century. In general, there seems to be an agreement that the risks associated with business startups are higher than for mature firms, hence, these ventures will have to pay a higher interest rate than more mature and large firms. In this paper the authors analyze the role of a relatively new form of financing for entrepreneurial ventures - crowdfunding - and how this form of financing is similar and different from traditional sources of finance. The authors are also presenting different forms and models of crowdfunding available on the market together with illustrations from the crowdfunding industry in Sweden. The analysis indicates that the positive effects with crowdfunding are numerous but that the size of the crowdfunding sector is relatively small in comparison with the banking and venture capital industry.
\end{abstract}

Keywords: crowdfunding, entrepreneurship, financing, SMEs, venture capital.

JEL Classification: G24, G32, M34.

\section{Introduction}

For the better half of the past century the financing of entrepreneurial ventures has been a widely debated issue among academic scholars as well as among policy-makers (cf. Macmillan, 1931; Bolton, 1971; Stanworth and Gray, 1991). In general, it seems as though small, entrepreneurial ventures have perennial problems in acquiring the financial resources that are necessary for growth. Since the beginning of the $20^{\text {th }}$ century, governments in nations all over the world have tried different strategies in promoting the quality and quantity of financing that is available to small entrepreneurial ventures.

The 1980s and 1990s witnessed a surge in the availability of venture capital for start-ups, especially within the ICT-sector. After the dot-com crash in March of 2000, the amount of venture capital invested in start-ups and growing entrepreneurial firms has plummeted in most industrialized nations (cf. Söderholm, 2011). Recent estimates in Sweden indicate an 80-90 percent decrease in the amount of capital invested from professional venture capital firms in early stages over the past decade (Söderholm, 2012). Whilst the formal venture capital market has downsized considerably, the informal venture capital, in the form of business angels seems to have experienced an upturn over the past decade (Jones-Evans and Thompson, 2009). Results from research in the U.S. indicate that conglomerations of business angels, so called business angel networks, have replaced the

(C) Lars Silver, Björn Berggren, Andreas Fili, 2016.

Lars Silver, Professor, Department of Business Administration, Umeå School of Business and Economics, Sweden.

Björn Berggren, Associate Professor, Department of Real Estate and Construction Management, KTH - The Royal Institute of Technology, Sweden.

Andreas Fili, Ph.D., Department of Real Estate and Construction Management, KTH - The Royal Institute of Technology, Sweden. role of formal venture capital firms in some parts of the country (Shane, 2012).

As uplifting at the increased momentum of the informal venture capital market may be, we know from earlier research that entrepreneurial ventures are very dependent on overdrafts and credits from the banks (Hall, 2010; Berger and Black, 2011). In most part of continental Europe, as well as other parts of the world, banks are the most important source of finance for small firms (Berger and Udell, 1998; Storey and Greene, 2010). The current financial crisis has, therefore, been detrimental to the expansion of many small firms (Jarvis and Schizas, 2012). An alternative to the traditional sources of finance described above is crowdfunding. The idea behind crowdfunding is to raise relatively small amounts of capital from a large number of people, i.e., the crowd (Belleflamme et al., 2014; Mollick, 2014).

Given the problems that entrepreneurial ventures often experience in their search for external financing, it is the purpose of this paper to analyze the role that crowdfunding might have for these ventures. We will present the different types of crowdfunding options that are available on the market today and compare them with other, more traditional sources of finance. We analyze the reward structure for the investor found in crowdfunding in terms of motivation theory and point to a number of implications. We finish the paper with an outlook for the future of crowdfunding.

\section{Financing entrepreneurial ventures}

An important theoretical point of departure for research on financing of SMEs is the principal agency theory (Jensen and Meckling, 1976), in that a major obstacle for SMEs seeking finance is the information asymmetry between financiers and 
entrepreneurs (Hall et al., 2000; Schmid, 2001; Hsu, 2004). It is often claimed that one of the main reasons that financiers shy away from early stage financing is the relatively high risk associated with these firms. The high risk exists because of a lack of information and the problems associated with accurately determining the firm's future market potential. To decrease the information asymmetry and resolve the problem of moral hazard, financiers make use of contracts or a higher frequency in the interactions between themselves and the entrepreneurs (Mason and Harrison, 2000; Shane and Stuart, 2002; Paul et al., 2003; Fili, 2014). Not all entrepreneurs, however, are comfortable with the resulting perception that they have lost control. In fact, many entrepreneurs choose not to grow because they feel that the drawback of lost control outweighs any potential benefits of growth (Gilbert et al., 2006).

Another strand of research in the financing of SMEs has been the pecking order framework or pecking order theory (Myers, 1984; Myers and Majluf, 1984). The pecking order theory states that entrepreneurs tend to choose the form of financing that enables them to retain control - that is, bank loans are preferred to private equity (Myers, 1984; Berggren et al., 2000; Howorth, 2001; De Jong et al., 2011). The origin of this theory is the notion of control aversion, which is the founder's or entrepreneur's perception that he is losing control to external actors (Lindström and Olofsson, 2001;
Saetre, 2003; Silver et al., 2010). The pecking order theory has been validated in numerous studies over the years in different settings and stages of the business cycle (Shyam-Sunder and Myers, 1999; De Jong et al., 2011). Even though many studies claim that private equity provides the greatest benefits for SMEs in terms of financier value-added (Bygrave et al., 2003; Knyphausen-Aufsess and Westphal, 2008; Berggren and Silver, 2009), the pecking order theory appears to explain the major factors determining financial behavior among entrepreneurs. According to the pecking order theory, entrepreneurs choose to grow more slowly - or not at all - to avoid the perception that they are losing control (cf. Howorth, 2001).

In the early stages of the firms' development, when the problem of information asymmetry is especially severe, the firms may have trouble accessing external finance. Instead, they will have to rely on other sources of capital (see Table 1 below). The major source of finance is, therefore, insider finance (Berger and Udell, 1998; Cassar, 2004). Insider finance includes the personal funds of the founder(s) plus what is traditionally referred to as the 3F: Family, Friends and Fools (Ennico, 2002; Bygrave, 2004). The owner-manager's personal funds typically include personal savings, home mortgage, and credit cards, while finance from friends and family can take the form of gifts or loans, or more seldom, equity ownership in the firm (Storey and Greene, 2010).

Table 1. Sources of finance for entrepreneurial ventures

\begin{tabular}{|l|l|l|}
\hline \multicolumn{1}{|c|}{ Source } & \multicolumn{1}{c|}{ Description } & \multicolumn{1}{c|}{ Typical type of finance } \\
\hline Founder & Personal funds of the founder & Equity \\
\hline 3F & Family, friends and fools & Equity or short term debt \\
\hline Suppliers & Buying supplies on credit & Short term debt \\
\hline Factoring & Selling invoices for cash & Short term debt \\
\hline Company credit card & Short-term cash credits & Short term debt \\
\hline Government grants & Receiving grants and subsidies & Short - medium term grants \\
\hline Leasing and hire purchase & Paying assets in installments & Medium-term deferred payment \\
\hline Banks & Loans provided by bank & Medium - long term debt \\
\hline Business angels & Business angel investment in firm & Equity \\
\hline Venture capital firms & VC firm investment in firm & Equity \\
\hline
\end{tabular}

For some entrepreneurial ventures capital from business angels and venture capital firms may constitute an important influx of capital, even though these ventures are a minority of all firms (cf. Black and Gilson, 1998; Li and Zahra, 2012).

\section{Crowdfunding - a background and overview}

The definition of crowdfunding is financial initiatives using the Internet to create support for projects, with or without profit maximization (Belleflamme et al., 2014; Ward and Ramachandran, 2010). The term crowdfunding can partly be attributed to the emerging microfinance community and in some cases still is correlated to this type of funding. The roots can also be traced to equity financing and small loan financing. A common denominator appears to be that crowdfunding has been especially useful for financing unique projects, creative or artistic, that generally find it hard to get support from more traditional sources of finance (Ordanini et al., 2011). Even political projects have been crowdfunded, for instance a majority of Barrack Obama's election campaign funds in 2008 came from small financial contributions (Eranti, 2014). Crowdfunding, in general, seeks out the small, private investor that supports a particular idea, often out of altruism or from having a particular interest. 
The most common form of crowdfunding is the threshold model, where the initiator introduces the project on an Internet platform, such as Kickstarter. The investor gets the opportunity to select one of a number of financial thresholds. For instance, for an investment of USD 50 the investor gets a book and an exclusive t-shirt, while for an investment of USD 100 the investor gets the book, the t-shirt and an autographed dedication in the book. The actual transfer only takes place if the project reaches a certain threshold needed to produce a certain item (in our example, a book). After specific time has been passed (a month or several months) the campaign is closed and payments are made.

One of the characteristics of crowdfunding is the reward system. A common distinction is that the investor obtains a social, financial or a material benefit, or a combination of the three (De Buyesere et al., 2012). The social benefit is the knowledge of helping to fund a particular project, in a given community with other enthusiasts. The financial benefit can be in the form of interest payments of loans or even equity. A material benefit is the access to an otherwise inaccessible commodity.

Over time a number of distinct types of crowdfunding alternatives has been developed, and, according to Hemer (2011), the following types can be found today:
1. Crowd donations: this is a model close to microfinancing where the reward often is limited to some token appreciation.

2. Crowd sponsoring: in crowd sponsoring the initiator and the investor agree on some kind of reward in the form of PR (which enhances the credibility and social standing of the investor).

3. Crowd pre-selling: in this case the compensation is the material award of buying a unique product before those not participating or even at the exclusion of those not participating.

4. Crowd lending, which, essentially, is an alternative to bank financing with a set model of interest paid. These initiatives are often separated from the more social forms of crowdfunding.

5. Crowd equity: in this case the donors are provided with a certain amount of shares in a profit-driven venture. This form of venture capitalism is one of the more complicated transactions in the crowdfunding area.

As can be seen above there are at least five distinct types of crowdfunding, and these types can be combined with a number of different business models. These include the threshold model, the microfinance model, the micro loan model, the equity model.

Table 2. Types of crowdfunding models

\begin{tabular}{|l|l|l|l|}
\hline \multicolumn{1}{|c|}{ Type of model } & \multicolumn{1}{c|}{ Raison d'etre } & \multicolumn{1}{c|}{ Compensation } \\
\hline Threshold model & Support creative ideas & Direct financing & Material (social) \\
\hline Microfinance model & Poverty alleviation & Donations & Social \\
\hline Microloan model & Alternative to banks & Bank loans & Financial (social) \\
\hline Equity model & Emerging enterprises & Business angels & Financial (social) \\
\hline
\end{tabular}

The threshold model has been a major success in supporting creative ideas. One of the largest sites, Kickstarter, has generated USD 1.7 billion since 2009 through the support of 8.7 million financiers (www.kickstarter.com). Over 85,000 projects have been financed in this way (through April 2015). There is a substantial amount of projects that have been over-financed, that is, passed the threshold and continues running. All money generated will be used and the supporters are allocated "stretch bonuses" as finance is being generated above the threshold, in the form of more bonuses. Many Kickstarter investors are enthusiasts supporting a specific hobby or specific creative ideas. Today, Kickstarter charges a fee of 5 percent for the services they provide. Not all projects are successful though, as close to 140,000 projects on Kickstarter failed to reach their targets.

One of the major microfinance crowdfunding platforms is Kiva that supports numerous small microfinance loans throughout the developing world. In essence, a project in the developing world, however small, can get financing through lenders or donors. This is in essence a microloan initiative especially for substituting aid through established NGO organizations, and avoids some of the large overhead costs of donating through these organizations. The loans are to be repaid and the repayment ratio for Kiva loans is close to 99 percent, which would be good even for small business start-up lending within the OECD countries. Kiva has contributed to 710 million USD in loans for 1.3 million lenders (through April 2015).

The micro loan model has been used by a number of platforms, many of which have surfaced as consumers have been critical to the way that the banks operate after the financial crisis and their lack of support for the business community. For instance, in Sweden almost 10 billion Euros has been reallocated from small business loans towards the private house mortgage market, showing that commercial banks in the eyes of many observers 
lack a social understanding of the plight of small businesses. At the same time, these alternative lenders have a relatively small proportion of the market: while the British Funding Circle (www.fundingcircle.com), has lent 645 million pounds to over 8000 enterprises, Aldermore, a private lender that started at the approximate same time, has lent 1.011 million pounds to small businesses and British banks total lending to small businesses is more than 110 billion pounds (Davis, 2012). The P2P-model (peer-to-peer financing) is similar to crowdfunding but has not got the overall support for creativity or reducing poverty that is the case in microfinance and threshold financing (De Buysere, 2012; FFE, 2012).

Equity crowdfunding is an even smaller, but growing, phenomenon where the British Crowdcube (www.crowdcube.com) has generated capital from 170000 investors for approximately 80 million pounds. There are similar initiatives in many countries, such as FundedByMe equity in Sweden. These initiatives purport to be business angel initiatives.

\section{Swedish crowdfunding initiatives}

Owing to the down-sizing of Swedish manufacturing industry since the 1990s, entrepreneurship in Sweden has been at the forefront of policy-makers' and politicians' agenda for quite some time. Among the most discussed issues there has been the financing of tomorrow's entrepreneurial champions. Therefore, it is no surprise that crowdfunding has become one of the proposed solutions to this perceived perennial problem.

3.1. Crowdcube. Crowdcube North is a Stockholmbased crowdfunding initiative that started in 2011. The Swedish initiative comes from a British forerunner. The mission of Crowdcube is to "help future entrepreneurs get on their feet, while also empowering ordinary people to make better informed investment decisions". The equity crowdfunding provided from Crowdcube is supposed to be an effective mean for young businesses to gain capital, valuable business networks and also positive wordof-mouth in relevant markets. In some cases, Crowdcube works with companies that have not started as a company. That is the capital is raised before the company actually opens for business. Therefore, the funding is perceived as seed money. Crowdcube uses an investment fee of USD 3000 , which is reduced by half if the campaign is unsuccessful. In addition, Crowdcube charges 5 percent of the raised capital. The campaign lasts for 60 days until the offer is closed.

The cited success stories typically originate for the United Kingdom. One example involves a firm wanting to develop their business by selling 23 percent of their shares to crowd investors, thereby raising USD 200000 in three months' time, which was seen by the company as more advantageous than lending from a bank at an interest rate of 15 percent. It is noteworthy that all of the examples listed in Crowdcubes homepage originate from the U.K. between 2011 and 2012 .

The founders of the Swedish Crowdcube initiative are headed by a Swedish entrepreneur with a rather diverse background. In addition, there are representatives from the successful British Crowdcube and some recently graduated students among the co-founders. Among success stories are campaigns for dairy-free icecream, ecological vodka, virtual gaming as well as funding of books and documentaries. The amounts are typically in the range of between USD 60000 and 125000 .

3.2. FundedByMe. FundedByMe is a crowdfunding platform that started in 2011 in Stockholm, Sweden. The vision for the platform was to create a userfriendly crowdfunding solution for European investors. FundedByMe is one of the first platforms where an investor can choose between reward-based, loan-based and equity-based crowdfunding within the same platform. The developers of the platform argue that the platform has a focus on cross-border investments that benefit job creation and economic growth. Crowdfunding is defined by FundedByMe as raising many small investments through the use of internet as a distribution channel.

FundedByMe was founded in February 2011 and claimed its pool of investors had a total of USD 300 million to invest each year.

Equity crowdfunding involves funding through investing in the equity of the company. The investors are also supposed to "provide valuable knowledge and access to networks". In loan-based crowdfunding loans are provided by the investors, these loans will also entitle investors to an interest fee. For German companies offering loans there is also the possible provision of a share of the profit. Reward-based crowdfunding involves the funding of a business by providing rewards for backing, such as early access to products, VIP treatments or merchandise. Different options for entrepreneurial ventures that FundedByMe have to offer are elaborated on below.

3.2.1. Equity-based crowdfunding. In equity-based crowdfunding, the company is supposed to be able to raise between USD 60000 to 180000 . The equity-based funding option is only made available to European investors and entrepreneurs. There is also a provision that anyone outside of the U.S. can participate in equity-based financing. For equity 
based campaigns FundedByMe charges an initial fee of USD 500 in addition to a fee of 8 percent of the total capital raised through the campaign.

3.2.2. Loan-based crowdfunding. In loan-based crowdfunding the company is also supposed to be able to raise between USD 60000 and 180000 . This option is only available to Swedish and German companies, but the lenders can provide capital worldwide. For loan based crowdfunding the total charge is a 5 percent success fee on money raised through the campaign.

3.2.3. Reward-based crowdfunding. In reward-based crowdfunding the entrepreneurs provide some kind of reward for the investors. In these cases the company may be provided with less than USD 60000 in small increments. This can be funded from all over the world. There is a maximum of 45 days to generate the funds required. FundedByMe charges 6 percent on the total capital raised for reward-based campaigns.

\section{Analysis of crowdfunding}

4.1. How crowdfunding handles different investment stages. In research on venture capital and business angels, there is often reference to the investment process, modeled somewhat differently by Tyebjee and Bruno (1984), Fried and Hisrich (1994) and Paul et al. (2007). Drawing on all three, the process starts with the origination of potential investments in the form of projects or startups. The origination stage is followed by screening and due diligence, where the potential investment is carefully examined. If it passes this stage, the investor and the investee engage in contracting. As the contract is finalized, the investee receives the funding. The stage following on contracting is often called managing, or monitoring. The final step in the process is harvesting, when the investor makes an exit from the investment. Ideally, an exit is a return on the capital invested by a factor of ten or more (for an overview of exit types, see Cumming and MacIntosh, 2003).

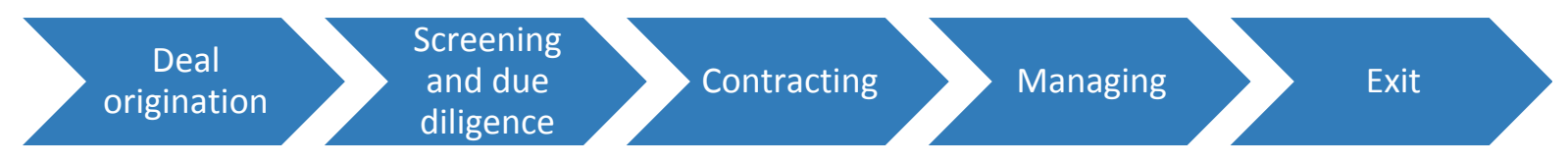

Fig. 1. The investment process of professional investors

Using this process model to understand crowdfunding, it is clear that crowdfunding provides a very elaborate mechanism for handling several of the stages in the process, but is less suited to deal with some of the others.

First, deal origination is handled in that projects in need of funding contact the crowdfunding actor. While deal origination is an important issue for financiers in order to attract potential investment objects, of at least equal importance is the issue of how to separate the good from the bad.

Screening and due diligence is a critical stage, where many potential investment objects are turned down because of lack of potential. Crowdfunding does not provide a way for handling screening and due diligence, something that is reflected in one of the major research topics for crowdfunding: the lack of proper regulations. There are always some doubts as to the validity of projects and how well the different hosts are able to curb fraudulent behavior, especially on part of the initiators. There is, undoubtedly, a temptation on the part of hosts to allow less thorough initiations to be made, and this is further exacerbated as the hosts typically lack the means to control the initiators and their plans. One of the main offsets of this is the relatively prevalent but still uneven control coming from social media that typically tend to follow these types of creative ideas. An initiative taken to improve the situation is the attempt to create a framework for controlling crowdfunding launched by organizations supported by the EU and different business angel organizations (De Buysere et al., 2012). In this attempt to create a framework, the emphasis lies on promoting regulation, education and research in the area. In addition, there needs to be a strong emphasis on transparency.

Next, contracting between investor and investee is handled neatly as well, since financiers are offered a contract for funding and reward, without any need for negotiation.

The next stage, managing, is the most important stage where investors add value to their firms through knowledge and networks (cf. Politis, 2008, for an overview of business angel value added). This stage is not at all present in crowdfunding. Thus, it seems that once the investee has received the funding, there is no more interaction between investor and investee. This seems natural since the large number of investors make personal interaction time consuming.

Finally, the financier's exit is clearly stated in the contract, and it seems, well defined and limited in scope. The contract stipulates that the financier should receive a product or a sum of money at a certain point in time. However, since the reward is 
such an important part of the crowdfunding logic, some attention should be devoted to the effect of different kinds of rewards on investors' satisfaction.

There is some limited research on crowdfunding, both regarding the hosts and the initiators, but very little research on the investors. Agrawal et al. (2011) have researched the SellaBand platform that supports initiatives in music. It turns out that the geographical distance between the initiator and the investors are somewhat correlated, especially as the closer the investor is, the less dependent the investor is on information generated solely by social media and Internet. Ward and Ramachandran (2010) support the notion that different investors look at the success of similar projects before signing on to projects. The likelihood that the initiator will be unable to perform the project due to lack of financing is important for the success of the model (Belleflamme et al., 2014), as investors will not provide funding if they believe that the project can succeed without their money.

Another aspect of investor research is the risk of crowding out. Crowding out roughly predicts that people can experience an inherent satisfaction from activities (intrinsic motivation), but that such an intrinsic motivation can be harmed by providing external, primarily financial, rewards (see Ryan and Deci, 2000, for an overview). By emphasizing certain aspects of crowd funding, firms may be able to increase intrinsic motivation and decrease extrinsic aspects; by focusing on the inherent satisfaction from being part of a common effort to achieve something.

The non-financial gains to crowdfunding financiers are beneficial in that they do not bring the adverse effects of crowding out but still carry a strong signaling and symbolic value (cf. Pfeffer and Sutton, 2006). To illustrate, one may imagine the motivations of two different kinds of investors. The first is from the threshold model, driven by a similar drive to achieve as the entrepreneur. In those cases, offering too much monetary incentives can produce crowding out effects. These would be primarily motivated by the intrinsic motivation of producing the product, the value in exchange (Grönroos, 2007) of receiving it for collection or use, and the social capital from being recognized by everyone else as one of the selected few able to do so.

The other kind of investor is from the equity model. These are not motivated by "owning gadgets", but by owning equity - however small - in exciting companies. Because of the minimal scale involved in crowdfunding, it is not so much the financial gains really, but a sense of importance. The intrinsic motivation for this kind of investor is derived from the contribution to various projects, while the social capital is gained from being recognized as an investor. Therefore, strengthening visibility among the owners would seem important. The value for the financier lies primarily in being recognized by peers (the other financiers) as a financier. Thus, the value lies in the relation with the firm and by extension of the other owners, in a value in use (Grönroos, 2007). The social capital does not necessarily arise from owning the finished product, but from the sense of belonging to the owners' club. Because of potential geographical distances (global pool of investors) and the sheer number of investors, maintaining a relational approach towards the investors may be difficult to implement. In spite of this, strengthening this social capital could be achieved through providing restricted - members only - interaction: online (forums, webpage, newsletter) as well as IRL meetings and gatherings.

\subsection{How crowdfunding complements existing}

financiers. The extent to which crowdfunding complements other financiers on the market, depends on whether the processes of funding are different. In essence, the four major versions of crowdfunding (threshold model, microfinance model, loan model and equity model) to an extent supplement banks, microfinancing NGOs and business angels.

Kiva supplements the microfinance model that has been established for a number of years in developing countries. These NGO microfinance models typically provide small loans with a short duration, frequent repayment and also with personal collateral as a major part of the structure. Kiva manages to alleviate some of the problems with that model, specifically that lenders now are in direct contact with borrowers, having greater control in what projects they want to support and with a faster feedback of results. The traditional NGO microfinancier may even be eliminated as a worthwhile intermediary. The drawback with the Kiva model is the reduction in local knowledge, which can partly be helped by frequent social media contacts.

The threshold model is in essence a form of trade credit (or project loan financing). By promising a specific product the producer is able to get a pledge that can be used to raise even more money. This can be a powerful tool in the hands of producers and definitely provides added opportunities to advance new projects in terms of finance. This is a product that cannot readily be replaced by loans or trade credits in a traditional sense. Thus, the threshold model can be seen as an original process.

The loan model is in fact not very different from the bank loan model that exists on the market. In this 
case it can be argued that the differences between the crowdfunding model and the existing alternative loan models are relatively small. There have also been prior attempts to start lending based on a social agenda, leading to some limited success.

The equity model is actually more akin to investing in shares on small stock exchanges rather than business angel financing. Since the investors generally have far less knowledge and influence in the portfolio companies, they are dependent on other mechanisms for assuring control over the portfolio firm. This is, therefore, a model that is very dependent on the actions of intermediaries. This is also the area in which it is hardest to obtain unbiased information.

\section{The promises of crowdfunding}

The importance of crowdfunding can be seen in two ways. On the one hand, it is in comparison with small business financing in general of a marginal influence. But it I, on the other hand, one of few initiatives available for supporting creative projects, and also rather unique in comparison with microfinancing, where it is now possible to see directly what kind of project one is financing. Crowdfunding is an extraordinary way for firms to try new ideas without committing financial resources. Some firms use Kickstarter explicitly to test ideas that are somewhat outside their core business and thereby are perceived as having a higher risk, and also in need of a new set of customers. Crowdfunding is a way of incorporating financial needs and risk management to investor demand, but will probably need a certain amount of altruism and social entrepreneurship associated to it. There is reason to believe that this is a valid idea, in particular, for doing what Internet is a great instrument for, connecting people with common interests on a worldwide basis.

From a macro perspective, crowdfunding could be perceived as a screening mechanism in itself, for larger investors. Once the project has received crowdfunding, it can be evaluated and those who seem to succeed can be approached by traditional investors such as business angels and venture capital funds.

Among the proponents and crowdfunding enthusiasts some important differences in relation to traditional sources of financing have been put forward. Among the more interesting ones have to do with geography. Most sources of finance, such as investments from business angels or credit from a local bank branch office, are dependent of face-toface meetings and interaction. With the advent of crowdfunding the constraints of being an entrepreneur in rural or lagging areas without access to a physical infrastructure becomes, less problematic. Furthermore, the dependence on one investment manager, investor or credit loan officer is reduced. Instead the decision to grant credit, donate money, or invest in equity is divided between thousands of potential creditors or investors. In a way this is a true democratization of the financial system that we have not seen before. Together with the expansion of social media in different forms, such as Facebook, this could potentially lead to a major change in the operation of financing for entrepreneurial ventures. At the very least, entrepreneurial ventures in some industries have more options available today than they had in the past. The challenge has to do with the scaling up of the industry.

The major difficulty with crowdfinance is that in comparison with business angel investments crowdfunding lacks two important ingredients that typically make or break small business equity investments. Firstly, in the crowdfunding initiatives there is a lack of experienced investors taking part in the investments. Successful business angel investors are usually perceived to be serial investors that have experience in investing in small businesses. In crowdfunding these serial investors are typically non-existent or not very vocal. Secondly, there is the lack of local knowledge. Business angels are typically local in their investments, partly because they have a good knowledge of local business initiatives, but also because a local investment philosophy may reinforce social network effects in making it more likely that the invested party will want to succeed in their business in order not to lose face socially. Overall, the information asymmetry is much higher in investments where the investor lacks experience and where the physical distance is great.

Finally, the traditional roles of financiers and customers become blurred when the same people are financing the start-up and at the same time are its customers. In a way this is also the case in companies within the paradigm of Open Innovation (Chesbrough, 2003). In future research, the impact of this multiplicity of roles on the dynamics over time of both goal convergence and divergence as well as of the motivations for investing could be studied.

\section{References}

1. Agrawal, A., Catalini, C. and Goldfarb, A. (2011). The geography of crowdfunding. NBER Working Paper.

2. Belleflamme, P., Lambert, T. and Schwienbacher, A. (2014). Crowdfunding: Tapping the right crowd, Journal of Business Venturing, 29 (5), pp. 585-609.

3. Berger, A.N. and Black, L.K. (2011). Bank size, lending technologies and small business finance, Journal of Banking and Finance, 35 (3), pp. 724-735. 
4. Berger, A.N. and Udell, G.F. (1998). The economics of small business finance: The roles of private equity and debt markets in the financial growth cycle, Journal of Banking and Finance, 22 (6-8), pp. 613-673.

5. Berggren, B., Olofsson, C. and Silver, L. (2000). Control aversion and the search for external financing in Swedish SMEs, Small Business Economics, 15 (3), pp. 233-242.

6. Berggren, B. and Silver, L. (2009). The effect of bridging networks on entrepreneurial activity: The rational-legal framework and embeddedness in local social capital networks, Journal of Enterprising Communities: People and Places in the Global Economy, 3 (2), pp. 125-137.

7. Black, B.S. and Gilson, R.J. (1998). Venture capital and the structure of capital markets: banks versus stock markets, Journal of Financial Economics, 47 (3), pp. 243-277.

8. Bolton, J.E. (1971). Report of the committee of inquiry on small firms. Cmnd. 4811, London: HMSO.

9. Bygrave, W. (2004). Founders, family, friends, and fools, Business Week, September 2, 2004.

10. Bygrave, W.D., Hay, M., Ng, E. and Reynolds, P.D. (2003). Executive forum: A study of informal investing in 29 nations composing the Global Entrepreneurship Monitor, Venture Capital, 5 (2), pp. 101-116.

11. Cassar, G. (2004). The financing of business start-ups, Journal of Business Venturing, 19 (2), pp. 261-283.

12. Chesbrough, H.W. (2003). Open Innovation: The new imperative for creating and profiting from technology. Boston: Harvard Business School Press.

13. Cumming, D.J. and MacIntosh, J.G. (2003). Venture capital exits in Canada and the United States, University of Toronto Law Journal, 53 (2), pp. 101-199.

14. Davis, A. (2012). Seeds of change: Emerging sources of non-bank funding for British SMEs. CSFI, Centre for the Study of Financial Innovation.

15. De Buysere, K., Gajda, O., Kleverlaan, R. and Marom, D. (2012). A framework for European crowdfunding. Available at: www.crowdfundingframework.eu.

16. De Jong, A., Verbeek, M., and Verwijmeren, P. (2011). Firms' debt - equity decisions when the static tradeoff theory and the pecking order theory disagree, Journal of Banking and Finance, 35 (5), pp. 1303-1314.

17. Ennico, C. (2002). Accepting money from friends and family: 4 ways to get your cash without wreaking havoc on your personal relationships, Entrepreneur.com, May 6.

18. Eranti, V. (2014). Crowdsourcing and crowdfunding a presidential campaign. Policy, 2012.

19. Fili, A. (2014). Business angel - venture negotiation in the post-investment relationship: the use of the good cop, bad cop strategy, Venture Capital, 16 (4), pp. 309-325.

20. FFE SMP Task Force. (2012). FFE Roundtable Series - Access to finance for SMEs, Federation of European Accountants, March.

21. Fried, V.H. and Hisrich, R.D. (1994). Toward a model of venture capital investment decision making, Financial Management, 23 (3), pp. 28-37.

22. Gilbert, B.A., McDougall, P.P. and Audretsch, D.B. (2006). New venture growth: A review and extension, Journal of management, 32 (6), pp. 926-950.

23. Grönroos, C. (2007). Service management and marketing: customer management in service competition. Wiley.

24. Hall, B.H. (2010). The financing of innovative firms, Review of Economics and Institutions, 1 (1), pp. 1-30.

25. Hall, G.C., Hutchinson, P.J. and Michaelas, N. (2000). Industry effects on the determinants of unquoted SMEs' capital structure, International Journal of the Economics of Business, 7 (3), pp. 297-312.

26. Hemer, J. (2011). A snapshot on crowdfunding. Working papers firms and regions, No. R2/2011.

27. Howorth, C.A. (2001). Small firms' demand for finance: A research note, International Small Business Journal, 19 (4), pp. 78-87.

28. Hsu, D.H. (2004). What do entrepreneurs pay for venture capital affiliation? The Journal of Finance, 59 (4), pp. 1805-1844.

29. Jarvis, R., and Schizas, E. (2012). Finance and the small business, in, Enterprise and Small Business: Principles, Practice and Policy, edited by S. Carter and D. Jones-Evans. London: Prentice Hall.

30. Jensen, M.C. and Meckling, W.H. (1976). Theory of the firm: Managerial behaviour, agency costs, and ownership structure, Journal of Financial Economics, 3 (4), pp. 305-360.

31. Jones-Evans, D. and Thompson, P. (2009). The spatial dispersion of informal investment at a regional level: Evidence from the UK, European Planning Studies, 17 (5), pp. 659-675.

32. Knyphausen-Aufsess, D. and Westphal, R. (2008). Do business angel networks deliver value to business angels? Venture Capital, 10 (2), pp. 149-169.

33. Li, Y. and Zahra, S.A. (2012). Formal institutions, culture, and venture capital activity: A cross-country analysis, Journal of Business Venturing, 27 (1), pp. 95-111.

34. Lindström, G. and Olofsson, C. (2001). Early stage financing of NTBFs: An analysis of contributions from support actors, Venture Capital, 3 (2), pp. 151-168.

35. Macmillan Committee. (1931). Report of the committee on finance and industry. Cmnd. 3897, London: HMSO.

36. Mason, C.M. and Harrison, R.T. (2000). Influences on the supply of informal venture capital in the UK: An exploratory survey of investor attitudes, International Small Business Journal, 18 (1), pp. 11-29.

37. Mollick, E. (2014). The dynamics of crowdfunding: An exploratory study, Journal of Business Venturing, 29 (1), pp. 1-16.

38. Myers, S.C. (1984). The capital structure puzzle, The Journal of Finance, 39 (3), pp. 575-592. 
39. Myers, S.C. and Majluf, N.S. (1984). Corporate financing and investment decisions when firms have information that investors do not have, Journal of Financial Economics, 13 (2), pp. 187-221.

40. Ordanini, A., Miceli, L., Pizzetti, M. and Parasuraman, A. (2011). Crowd-funding: transforming customers into investors through innovative service platforms, Journal of Service Management, 22 (4), pp. 443-470.

41. Paul, S., Whittam, G. and Johnston, J.B. (2003). The operation of the informal venture capital market in Scotland, Venture Capital, 5 (4), pp. 313-335.

42. Paul, S., Whittam, G. and Wyper, J. (2007). Towards a model of the business angel investment process, Venture Capital, 9 (2), pp. 107-125.

43. Pfeffer, J., and Sutton, R.I. (2006). Hard facts, dangerous half-truths, and total nonsense: Profiting from evidencebased management. Harvard: Harvard Business School Press.

44. Politis, D. (2008). Business angels and value added: What do we know and where do we go? Venture Capital, 10 (2), pp. 127-147.

45. Ryan, R.M. and Deci, E.L. (2000). Intrinsic and extrinsic motivations: Classic definitions and new directions, Contemporary Educational Psychology, 25 (1), pp. 54-67.

46. Saetre, A.S. (2003). Entrepreneurial perspectives on informal venture capital, Venture Capital, 5 (1), pp. 71-94.

47. Schmid, F. (2001). Equity financing and the entrepreneurial firm. Federal Reserve Bank of St Louis Review, 83 (1), pp. 15-28.

48. Shane, S. (2012). The importance of angel investing in financing the growth of entrepreneurial ventures, The Quarterly Journal of Finance, 2 (2), pp. 1-42.

49. Shane, S. and Stuart, T. (2002). Organizational endowments and the performance of University start-ups, Management Science, 48 (1), pp. 154-170.

50. Shyam-Sunder, L. and Myers, S.C. (1999). Testing static tradeoff against pecking order models of capital structure, Journal of Financial Economics, 51 (2), pp. 219-244.

51. Silver, L., Berggren, B. and Vegholm, F. (2010). The impact of investment readiness on investor commitment and market accessibility in SMEs, Journal of Small Business and Entrepreneurship, 23 (1), pp. 81-95.

52. Stanworth, J. and Gray, C. (1991). Bolton 20 years on: The small firm in the 1990s. University of Illinois at Urbana-Champaign's Academy for Entrepreneurial Leadership Historical Research Reference in Entrepreneurship.

53. Storey, D.J. and Greene, F.J. (2010). Small Business and Entrepreneurship. Harlow: Pearson.

54. Söderblom, A. (2011). Private equity fund investing: Investment strategies, entry order and performance. Doctoral dissertation, Stockholm School of Economics.

55. Söderblom, A. (2012). The current state of the venture capital industry in relation to other financing sources for startup firms. Entreprenörskapsforum, Stockholm.

56. Tyebjee, T.T. and Bruno, A.V. (1984). A model of venture capitalist investment activity, Management Science, 30 (9), pp. 1051-1066.

57. Ward, C. and Ramachandran, V. (2010). Crowdfunding the next hit: Microfunding online experience goods, In Workshop on Computational Social Science and the Wisdom of Crowds at NIPS2010. 